\title{
Molecular characterization of the myxosporean associated with parasitic encephalitis of farmed Atlantic salmon Salmo salar in Ireland
}

\author{
S. Frasca Jr ${ }^{1, *}$, D. R. Linfert ${ }^{2}$, G. J. Tsongalis ${ }^{2}$, T. S. Gorton ${ }^{1}$, A. E. Garmendia ${ }^{1}$, \\ R. P. Hedrick ${ }^{3}$, A. B. West ${ }^{4}$, H. J. Van Kruiningen ${ }^{1}$ \\ ${ }^{1}$ Department of Pathobiology, U-89, University of Connecticut, Storrs, Connecticut 06269-3089, USA \\ ${ }^{2}$ Department of Pathology and Laboratory Medicine, Hartford Hospital, Hartford, Connecticut 06102, USA \\ ${ }^{3}$ Department of Medicine and Epidemiology, School of Veterinary Medicine, One Shields Avenue, University of California, \\ Davis, California 95616, USA \\ ${ }^{4}$ Department of Pathology, University of Texas Medical Branch, Galveston, Texas 77555, USA
}

\begin{abstract}
During seasonal epizootics of neurologic disease and mass mortality in the summers of 1992, 1993 and 1994 on a sea-farm in Ireland, Atlantic salmon Salmo salar smolts suffered from. encephalitis associated with infection by a neurotropic parasite. Based on ultrastructural studies, this neurotropic parasite was identified as an intercellular presporogonic multicellular developmental stage of a histozoic myxosporean, possibly a Myxobolus species. In order to generate sequence data for phylogenetic comparisons to substantiate the present morphological identification of this myxosporean in the absence of detectable sporogony, polymerase chain reaction (PCR), Southern blot hybridization, dideoxynucleotide chain-termination DNA sequencing, and in situ hybridization (ISH) were used in concert to characterize segments of the small subunit ribosomal RNA. (SSU rRNA) gene. Oligonucleotide primers were created from sequences of the SSU rRNA gene of $M$. cerebralis and were employed in PCR experiments using DNA extracted from formalin-fixed paraffin-embedded tissue sections of brains from Atlantic salmon smolts in which the myxosporean had been detected by light microscopy. Five segments of the SSU IRNA gene of the myxosporean, ranging in length from 187 to 287 base pairs, were amplified, detected by hybridization with sequence-specific probes, and sequenced. Consensus sequences from these segments were aligned to create a partial sequence of the SSU rRNA gene of the myxosporean. Assessments of sequence identity were made between this partial sequence and sequences of SSU rRNA genes from 7 myxosporeans, including Ceratomyxa shasta, Henneguya doori, $M$. arcticus, $M$. cerebralis, $M$. insidiosus, $M$. neurobius, and $M$. squamalis. The partial SSU rRNA gene sequence from the myxosporean had more sequence identity with SSU IRNA gene sequences from neurotropic and myotropic species of Myxobolus than to those from epitheliotropic species of Myxobolus or Henneguya, or the enterotropic species of Ceratomyxa, and was identical to regions of the SSU rRNA gene of $M$. cerebralis. Digoxigenin-labeled oligonucleotide DNA probes complementary to multiple segments of the SSU rRNA gene of $M$. cerebralis hybridized with DNA of the parasite in histologic sections of brain in ISH experiments, demonstrating definitively that the segments of genome amplified were from the organisms identified by histology and ultrastructural analysis. Based on sequence data derived entirely from genetic material of extrasporogonic stages, the SSU rDNA sequence identity discovered in this study supports the hypothesis that the myxosporean associated with encephalitis of farmed Atlantic salmon smolts is a neurotropic species of the genus $\mathrm{MyXo}$ bolus, with sequences identical to those of $M$. cerebralis.
\end{abstract}

KEY WORDS: Atlantic salmon · Myxosporean - Myxobolus cerebralis · Small subunit ribosomal DNA $\mathrm{PCR} \cdot$ In situ hybridization 


\section{INTRODUCTION}

In the summers of 1992, 1993 and 1994, epizootics of parasitic encephalitis and mass mortality occurred in netpen-reared Atlantic salmon Salmo salar smolts on a sea-farm in Ireland, with mortalities that exceeded $90 \%$ of total smolt stocks in 1993 alone (Rodger et al. 1995, Scullion et al. 1996). Prior to death, affected smolts displayed neurologic clinical signs which included gyrating and circling swimming patterns, inappropriate postures in the water column, and periods of apparent unconsciousness (Rodger et al. 1995). Epizootiologic studies conducted in the winter of 1995 revealed that parasitic infection was detectable with and without host inflammatory cell infiltrates and that netpen populations of infected smolts neither developed neurologic clinical signs nor underwent significant increases in cumulative mortalities (Frasca et al. 1998).

The ultrastructural morphology of the parasite associated with encephalitis of Atlantic salmon smolts was consistent with that of an intercellular presporogonic multicellular developmental stage of a histozoic myxosporean, having morphologic features shared by proliferative stages of members of Family Myxobolidae (Frasca et al. 1998). No spores of this myxosporean were detected in histologic sections of brain or coelomic viscera (Rodger et al. 1995, Frasca et al. 1998). Because taxonomic classification of myxosporeans is currently based on spore morphology (Lom \& Dyková 1992), the absence of detectable spores in tissues of infected smolts precluded definitive taxonomic classification of this myxosporean in much the same way as the absence of detectable spores from sites of inflammation hampered taxonomic classifications of the myxosporeans responsible for proliferative kidney disease (Kent \& Hedrick 1985) and proliferative gill disease (Hedrick et al. 1990).

Comparative analyses of eukaryotic small subunit ribosomal RNA (SSU rRNA) gene sequences have been employed to evaluate phylogenetic distances between and within taxomonic groups of organisms (Sogin et al. 1986, Gunderson et al. 1987, Sogin \& Gunderson 1987); this is possible because the SSU IRNA gene is universally distributed, functionally equivalent, and occurs in sizes large enough that interspersion patterns of conserved and nonconserved regions allow for statistically valid interpretations of genetic relatedness (Sogin \& Gunderson 1987). SSU rRNA gene sequences have been used to develop sensitive and specific molecular diagnostic tests and to elucidate taxonomic relationships between members of both the Microspora and the Myxozoa (Kent et al. 1996). Such molecular techniques can overcome the shortcomings of other diagnostic techniques, such as light and electron microscopy, when pathogens are present in small numbers and lack easily detectable morphologic criteria for their speciation (Fedorko \& Hijazi 1996).

The application of molecular techniques to the study of myxosporeans has provided further evidence elucidating their phylogenetic relationships and life cycles. SSU rDNA sequence analyses have supported the morphologically derived hypothesis that myxozoans are more closely related to metazoans than to protozoans (Smothers et al. 1994, Siddall et al. 1995, Schlegel et al. 1996), and SSU rDNA sequences have been used to unite alternate actinosporean and myxosporean stages of Myxobolus cerebralis (Andree et al. 1997 ) in support of the actinosporean-myxosporean alternation theory of Wolf \& Markiw (1984). Of the 1200 species of myxosporeans, SSU rDNA sequences have been determined for a small number of species from several genera, including Ceratomyxa (Bartholomew et al. 1997), Henneguya (Kent et al. 1996), Kudoa (Kent et al. 1996), Myxobolus (Smothers et al. 1994. Andree et al. 1999), and Myxidium (Schlegel et al. 1996), allowing for sequence comparisons to determine the genetic relatedness of isolates.

In this study, we characterized segments of the SSU rRNA gene from proliferative stages of a myxosporean associated with encephalitis of farmed Atlantic salmon. The resultant SSU rDNA sequence data was used to elucidate the phylogenetic relationship of this myxosporean to others and confirmed that it was most likely a neurotropic species of the genus Myxobolus.

\section{METHODS}

Sample acquisition. The brains of 12 clinically normal Atlantic salmon Salmo salar smolts from a freshwater hatchery with no history of parasitic encephalitis or recent disease were collected at necropsy in 1997 and fixed in $1.5 \%$ paraformaldehyde, $1.5 \%$ glutaraldehyde, and $3 \mathrm{mM} \mathrm{MgCl}_{2}$ in $0.1 \mathrm{M}$ sodium cacodylate buffer ( $\mathrm{pH}$ 7.3) for 3 d prior to paraffin embedding. These brains served as the source of genomic Atlantic salmon DNA (i.e. negative control DNA).

Brains of 20 Atlantic salmon smolts that died or suffered from neurologic disease during an epizootic of mass mortality at Site A (Frasca et al. 1998) in 1994 served as the source of parasite DNA (i.e. test DNA). These brains were collected at necropsy in 1994 and stored in $10 \%$ neutral buffered formalin at $4{ }^{\circ} \mathrm{C}$ for $3 \mathrm{yr}$.

Three rainbow trout Oncorhynchus mykiss fingerlings, experimentally infected with the triactinomyxon stage of Myxobolus cerebralis, were obtained from the Fish Health Laboratory, University of California, Davis, California, USA, fixed whole in $10 \%$ neutral buffered 
formalin for $3 \mathrm{~d}$, and embedded in paraffin. These samples served as the source of myxobolid DNA (i.e. positive control DNA). $M$. cerebralis was selected because it is a neurotropic myxobolid, it shares ultrastructural features with the Atlantic salmon parasite and members of Family Myxobolidae iEl-Matbouli et al. 1995, Frasca et al. 1998), and its SSU rRNA gene has been sequenced (Andree et al. 1997).

Sample evaluation and target selection. To ascertain that myxosporeans were present in tissue sections for DNA extraction, Atlantic salmon brains and rainbow trout fingerlings were sliced sagittally along the median longitudinal axis, routinely processed for paraffin embedding, sectioned at $3 \mu \mathrm{m}$, stained with hematoxylin and eosin (H\&E), and examined by light microscopy. Whenever myxosporean parasites were detected, 2 sequential $5 \mu \mathrm{m}$ sections were cut for DNA extraction. Histologic sections of control Atlantic salmon brains were examined to ensure that no myxosporeans were detectable by light microscopy, and 2 successive $5 \mu \mathrm{m}$ sections were submitted for extraction.

DNA extraction and quantification. DNA was extracted using the QIAamp DNA extraction system (Qiagen Inc., Chatsworth, CA, USA) according to the manufacturer's protocol for paraffin-embedded tissue, except that samples were lysed in tissue lysis buffer with $400 \mu \mathrm{g}$ proteinase $\mathrm{K}$ at $55^{\circ} \mathrm{C}$ for 3 to $5 \mathrm{~d}$. After a 3-step elution, DNA was quantitated by UV spectrophotometry. Eluates from samples that did not register absorbance readings for DNA were combined, subjected to an additional round of membrane absorption and washes, eluted with preheated elution buffer to a final volume of $100 \mu l$, and quantitated again.

Synthesis of primers. Oligonucleotide primers for amplification of myxosporean DNA in polymerase chain reaction (PCR) experiments were designed from sequences of the SSU rRNA gene of Myxobolus cerebralis (Andree et al. 1997), except for SM5-3, which was designed from a conserved region of the SSU rRNA genes of $M$. cerebralis, $M$. arcticus, and $M$. neurobius (Andree et al. 1999). Primers were tested for self-complementarity or homodimer and heterodimer formation using the computer software programs Amplify (University of Wisconsin Genetics, Madison, WI, USA) and Oligo 4.05 (National Biosciences, Inc., Plymouth, MN, USA). Primers for PCR and DNA sequencing reactions were prepared either by Gibco BRL (Gaithersburg, MD, USA) or the University of Connecticut Biotechnology
Center (Storrs, CT, USA). The sequences of the primers and their positions relative to the $M$. cerebralis SSU rRNA gene are listed in Table 1.

Polymerase chain reaction amplification of DNA. In order to determine whether extractions from paraffinembedded tissues had yielded amplifiable DNA, samples were subjected to PCR amplification using oligonucleotide primers designed from a segment of the repetitive $\mathrm{Bg} / \mathrm{I}$ element of the Atlantic salmon genome (Goodier \& Davidson 1993). The sequence of the forward primer (5'-CCCTCTTGCTGTATCTCTCATTG-3') corresponded to positions 11 to 36 of the $\mathrm{Bg} / \mathrm{I}$ element (GenBank L01505), and the sequence of the reverse primer (5'-CCACTGTGGTCCCAAGTCAGT-3') corresponded to positions 707 to 727 (Moran et al. 1997). DNA was amplified in $50 \mu \mathrm{l}$ reactions containing 100 to $500 \mathrm{ng}$ of sample DNA, $5 \mu \mathrm{l} 10 \times$ Buffer I (100 mM Tris$\mathrm{HCl}, \mathrm{pH} 8.3,500 \mathrm{mM} \mathrm{KCl}, 15 \mathrm{mM} \mathrm{MgCl}, 0.01 \%$ gelatin), $200 \mu \mathrm{M}$ dNTPs, $40 \mathrm{ng} \mathrm{\mu l}^{-1}$ forward and reverse primers, and 2 U AmpliTaq Gold polymerase (Perkin-Elmer, Foster City, CA, USA). PCR was performed in a Perkin-Elmer Model $\# 2400$ thermal cycler. Reactions were initiated by a 9 min incubation at $94^{\circ} \mathrm{C}$, followed by 40 amplification cycles, each consisting of a 1 min denaturation step at $94^{\circ} \mathrm{C}$, a 1 min primer annealing step at $55^{\circ} \mathrm{C}$, and a 1 min extension step at $72^{\circ} \mathrm{C}$. A prolonged extension step of $10 \mathrm{~min}$ at $72^{\circ} \mathrm{C}$ completed each reaction. PCR products were separated by electrophoresis in $8 \%$ polyacrylamide gels, visualized using ethidium bromide staining and UV trans-illumination, and recorded using a Stratagene Eagle Eye II-Still Video System (Stratagene Inc., LaJolla, CA, USA).

Multiple segments of the SSU rRNA gene from the myxosporean parasite were amplified using 5 different primer pairs (Table 1). DNA was amplified in separate

Table 1. Oligonucleotide primers used to amplify myxosporean DNA in polymerase chain reactions. Location refers to the position of the primer relative to the nucleotide sequence of the Myxobolus cerebralis small subunit ribosomal RNA (SSU rRNA) gene

\begin{tabular}{|c|c|c|c|c|}
\hline Primer & $5^{\prime} \rightarrow 3^{\prime}$ sequence & Location & $\begin{array}{l}\text { Reverse } \\
\text { primer }\end{array}$ & $\begin{array}{l}\text { Product } \\
\text { size }\end{array}$ \\
\hline SM5-3 & CGCAGTGTAAGTTGGTAAGCTGA & $639-661$ & SM3-5 & $287 \mathrm{bp}$ \\
\hline SM3-5 & CGTTATTGGTGGTTGGTGCTG & $948-968$ & & \\
\hline SM5-4 & AGGACTAACGAATGCGAAGG & $1059-1078$ & SM3-4 & $187 \mathrm{bp}$ \\
\hline SM3-4 & CGTCAATTCCTTTAAGTTTCAGC & $1265-1287$ & & \\
\hline SM5-6 & GAGAAACGGCTACCACATCCAT & $394-416$ & SM3-6 & $247 \mathrm{bp}$ \\
\hline SM3-6 & GAGCAGTTAGTAGCACCATTCG & $663-684$ & & \\
\hline SM5-7 & GTTTTTCGGTTACGGGGAGAG & $1232-1252$ & SM3-7 & $244 \mathrm{bp}$ \\
\hline SM3-7 & ATCATCGAGCTACACTATCTTCTTC & $1496-1520$ & & \\
\hline SM5-8 & TATTCTCCATTTGATGAGCGGAAG & $1476-1499$ & SM3-8 & $258 \mathrm{bp}$ \\
\hline SM3-8 & GGACATCTTAGGGCATCACAGACC & $1757-1780$ & & \\
\hline
\end{tabular}


$50 \mu$ reaction mixtures, as described above. Reactions were initiated by a $9 \mathrm{~min}$ incubation at $94^{\circ} \mathrm{C}$, followed by 40 amplification cycles, each consisting of a $30 \mathrm{~s}$ denaturation step at $94^{\circ} \mathrm{C}$, a $45 \mathrm{~s}$ primer annealing step at $50^{\circ} \mathrm{C}$, and a $30 \mathrm{~s}$ extension step at $72^{\circ} \mathrm{C}$. Reactions were completed with a prolonged extension step of $10 \mathrm{~min}$ at $72^{\circ} \mathrm{C}$. Amplification products were separated by electrophoresis in either $2 \%$ agarose or $8 \%$ polyacrylamide gels.

Southern hybridization. Digoxigenin-labeled DNA probes used in Southern hybridizations were created by random oligonucleotide primed synthesis according to the manufacturer's directions for the High Prime labeling kit (Boehringer Mannheim Corp., Indianapolis, IN, USA) and using Klenow fragment polymerase, a mixture of deoxyribonucleoside-triphosphates containing digoxigenin-labeled deoxyuridine-triphosphate (DIG DNA Labeling Mix, $10 \times$ conc., Boehringer Mannheim Corp.), and PCR product amplified from positive control DNA.

Amplification products were separated by electrophoresis in $2 \%$ agarose gels, depurinated in $0.25 \mathrm{M}$ $\mathrm{HCl}$ for $5 \mathrm{~min}$, rinsed in distilled $\mathrm{H}_{2} \mathrm{O}$, and denatured in $0.1 \mathrm{M} \mathrm{NaOH}$ for 15 to $20 \mathrm{~min}$. DNA was transferred to nylon membranes (Boehringer Mannheim Corp.) by capillary action using $10 \times$ sodium chloride-sodium citrate (SSC) buffer in standard Southern transfer pyramids with transfer times ranging from $3 \mathrm{~h}$ to overnight and was fixed by incubation at 80 to $90^{\circ} \mathrm{C}$ for $30 \mathrm{~min}$. Blots were incubated with $20 \mathrm{ml}$ of prehybridization solution (equal parts of DIG Easy Hyb solution [Boehringer Mannheim Corp.] and $5 \times \mathrm{SSC}, 1 \%$ glycine, $1 \%$ SDS [sodium dodecyl sulfate], $45 \%$ deionized formamide, and $10 \%$ dextran sulfatej per $100 \mathrm{~cm}^{2}$ of membrane for 1 to $2 \mathrm{~h}$, followed by overnight incubation with 13 to $15 \mathrm{ml}$ of hybridization solution $(5 \times$ SSC, $1 \%$ glycine, $1 \%$ SDS, $45 \%$ deionized formamide, $10 \%$ dextran sulfate, and probe at 8 to $10 \mathrm{ng} \mathrm{ml}^{-1}$ ). After hybridization, blots were washed, blocked with a solution of $1 \%(\mathrm{w} / \mathrm{v})$ blocking reagent in $0.1 \mathrm{M}$ maleic acid buffer for $30 \mathrm{~min}$, and incubated with 1:10000 dilution of sheep polyclonal anti-digoxigenin Fab fragments conjugated to alkaline phosphatase (Boehringer Mannheim Corp.) for $30 \mathrm{~min}$ at room temperature. Blots were dipped in CSPD (Boehringer Mannheim Corp.), and incubated in the dark for $10 \mathrm{~min}$ at room temperature, followed by $5 \mathrm{~min}$ at $37^{\circ} \mathrm{C}$. Radiographic films were exposed to processed blots for 1 to $10 \mathrm{~min}$ and developed routinely.

Sequencing of PCR products and sequence alignments. For each of the 5 different primer pairs, $5 \mu \mathrm{l}$ samples from at least 5 separate PCR mixtures that yielded detectable product were subjected to a second round of PCR to generate amplicons in sufficient concentration to serve as templates in sequencing reac- tions. Second-round PCR products were purified (QIAquick PCR Purification Kit, Qiagen Inc.), visualized in $8 \%$ polyacrylamide gels, compared to molecular weight markers to estimate their concentrations, and submitted for sequencing.

Nucleotide sequences were determined by oligonucleotide-directed dideoxynucleotide chain-termination cycling sequencing reactions performed by the HHMI Biopolymer/W. M. Keck Foundation Biotechnology Resource Laboratory at Yale University, New Haven, Connecticut, USA, using an automated Applied Biosystems 377 DNA sequencer (Perkin-Elmer), 10 to $20 \mathrm{ng}$ of template DNA per 200 bases of product, $27 \mathrm{ng}$ $\mu^{-1}$ forward or reverse PCR primers, and AmpliTaq FS DNA polymerase. MarDNAsis version 3.5 (Hitachi Software Engineering America, Ltd, San Bruno, CA, USA) was used to generate consensus sequences of the products from each primer pair through the alignment of a minimum of 5 single-stranded and 10 doublestranded sequences. Discrepancies at base positions were resolved by simple majority rule. The resultant consensus sequences were aligned to create a partial SSU rDNA sequence of the parasite, which was compared to the SSU rRNA gene sequences of 3 neurotropic myxobolids, e.g. Myxobolus arcticus, $M$. cerebralis and $M$. neurobius.

Analysis of percent sequence identity. Assessments of percent sequence identity were obtained by comparison of the consensus SSU rDNA sequence of the Atlantic salmon parasite with the SSU rDNA sequences of 7 myxosporeans, including several neurotropic myxobolids of salmon (Myxobolus arcticus [Andree et al. 1999], $M$. cerebralis [Genbank accession no. U96493], and $M$. neurobius [Andree et al. 1999]), a myotropic myxobolid of salmon ( $M$. insidiosus [U96494]), 2 epitheliotropic myxosporeans (one of salmonid hosts, $M$. squamalis [U96495], and one of non-salmonid hosts, Henneguya doori [HDU37549]), and a non-myxobolid enterotropic myxosporean of salmon from Family Ceratomyxidae (Ceratomyxa shasta [AF001579]). Selection of species for sequence comparisons was based on availability of complete SSU rRNA gene sequence data, tissue tropism, host range, and phylogenetic classification. Percent sequence identities were calculated using MacDNAsis version 3.5 (Hitachi Software Engineering America, Ltd).

Preparation of tissue sections and probes for in situ hybridization. The paraffin-embedded tissue blocks, which had been prepared for target selection for PCR, were used in the in situ hybridization (ISH) experiments. Tissue sections were cut at $4 \mu \mathrm{m}$, mounted on glass slides, stained with H\&E, and examined by light microscopy. Whenever foci of parasites were identified in these sections, successive serial tissue sections were cut at $4 \mu \mathrm{m}$, mounted un- 
stained on silane-coated glass slides, and submitted for ISH experiments.

Digoxigenin-labeled single-stranded oligonucleotide DNA probes complementary to sequences specific to the SSU rRNA gene of Myxobolus cerebralis (i.e. Tr5-16, $\operatorname{Tr} 3-16, \operatorname{Tr} 3-17)$ were synthesized by Genmed Synthesis Inc., San Francisco, California, USA, and were labeled at their $3^{\prime}-\mathrm{OH}$ ends with digoxigenin-11deoxyuridine triphosphate in standard tailing reactions. The nucleotide sequences of probes and their positions relative to the $M$. cerebralis rRNA gene are listed in Table 2.

In situ hybridization procedure. The protocol for in situ hybridization (ISH) was based on procedures described by Crabbe et al. (1992), Gan et al. (1994), and Antonio et al. (1998). The ISH was performed using an automated GenII In Situ Hybridization Processor (Ventana Medical Systems Inc., Tucson, AZ, USA) in the Department of Pathology, University of Texas Medical Branch, Galveston, Texas, USA. Unstained tissue sections mounted on silane-coated glass slides were deparaffinized, rehydrated, incubated for 3 min in Tris- $\mathrm{CaCl}_{2}$ buffer ( $\mathrm{pH}$ 7.2), and digested for $24 \mathrm{~min}$ in a solution of proteinase $\mathrm{K}\left(200 \mu \mathrm{g} \mathrm{ml}^{-1}\right)$ and $10 \mathrm{mM}$ Tris buffer ( $\mathrm{pH}$ 7.5). After digestion, sections were covered with $100 \mu \mathrm{l}$ of hybridization solution $(5.0 \mathrm{ml}$ deionized formamide, $2.0 \mathrm{ml} 20 \times \mathrm{SSC}, 0.5 \mathrm{ml}$ of dextran sulfate, $0.2 \mathrm{ml}$ of $50 \times$ Denhardt's solution) containing a mixture of 3 digoxigenin-labeled DNA probes each at $5 \mathrm{ng} \mu \mathrm{l}^{-1}$, heated to $95^{\circ} \mathrm{C}$ for $5 \mathrm{~min}$, and hybridized for $10 \mathrm{~h}$ at $37^{\circ} \mathrm{C}$. Following three $4 \mathrm{~min}$ washes with $2 \times \mathrm{SSC}$ at $42^{\circ} \mathrm{C}$, slides were incubated for $32 \mathrm{~min}$ at $42^{\circ} \mathrm{C}$ in an anti-digoxigenin antibody solution consisting of $2 \%$ normal sheep serum, $0.3 \%$ Triton $\mathrm{X}-100$, and $1: 100$ dilution of sheep polyclonal antidigoxigenin Fab fragments conjugated to alkaline phosphatase (Boehringer Mannheim Corp.). Slides were washed multiple times at $42^{\circ} \mathrm{C}$ in alkaline phosphatase $\mathrm{K}(\mathrm{APK})$ washing solution (Ventana Medical System Inc.), immersed in color substrate solution consisting of 4-nitro blue tetrazolium chloride (NBT $75 \mathrm{mg}$ $\mathrm{ml}^{-1}$ in $70 \%$ dimethylformamide) and 5-bromo-4chloro-3-indolylphosphate (X-phosphate $50 \mathrm{mg} \mathrm{ml}^{-1}$ in $100 \%$ dimethylformamide) in color substrate buffer (100 mM Tris- $\mathrm{HCl}, 100 \mathrm{mM} \mathrm{NaCl}$, and $50 \mathrm{mM} \mathrm{MgCl}_{2}$ at

Table 2. Oligonucleotide DNA probes used in the in situ hybridization experiments. Location refers to the position of the probe relative to the nucleotide sequence of the SSU rRNA gene of Myxobolus cerebralis

\begin{tabular}{|c|c|c|}
\hline Probe & $5^{\prime} \rightarrow 3^{\prime}$ sequence & Location \\
\hline $\operatorname{Tr} 5-16$ & GCATTGGTTTACGCTGATGTAGCGA & $212-237$ \\
\hline $\operatorname{Tr} 3-16$ & GAATCGCCGAAACAATCATCGAGCTA & $1509-1535$ \\
\hline $\operatorname{Tr} 3-17$ & GGCACACTACTCCAACACTGAATTTG & $698-723$ \\
\hline
\end{tabular}

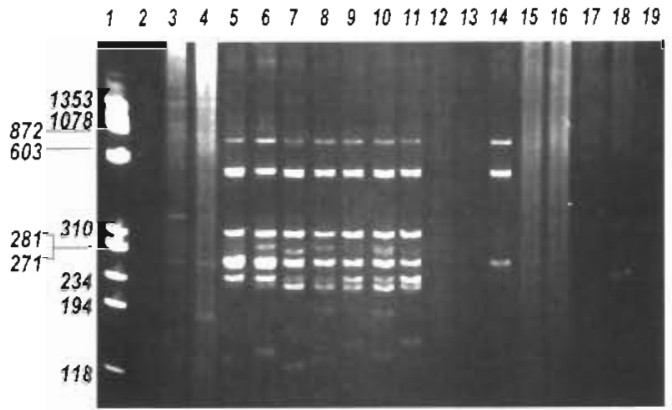

Fig. 1. Polyacrylamide gel electrophoresis $(8 \%)$ of PCR products from paraffin-embedded tissues using primers to the repetitive $\mathrm{Bg} / \mathrm{I}$ element of Salmo salar. Lane 1. PhiX174 DNAJHae III molecular weight marker (Promega Corp., Madison, WI, USA). Lane 2: reagent control. Lanes 3 and 4: Oncorhynchus keta genomic DNA (Sigma Chemical Co., St. Louis, MO, USA). Lanes 5 and 6: repeated extractions of $S$ salar genomic DNA from uninfected smolt brains fixed in 1997. Lanes 7 to 11: S. salar genomic DNA from uninfected smolts fixed in 1997 (i.e. negative control DNA). Lanes 12 to 16: DNA from myxosporean-infected S. salar fixed in 1994 (i.e. test DNA). Lanes 17 and 18: DNA from Myxobolus cerebralis-infected Oncorhynchus mykiss fixed in 1997 (i.e. positive control DNA). Lane 19: human genomic DNA. Uninfected S. salar DNA from 1997 yielded multiple products at approximately $700,560,290,250$, and 225 base pairs, whereas 1 sample of myxosporean-infected S. salar DNA from 1994 yielded products at 700,560 , and 250 base pairs (Lane 14). Faint bands are detectable in Lanes 3, 4, and 18 from DNA of Oncorhynchus spp. There was no amplification of human genomic DNA (Lane 19)

$\mathrm{pH}$ 9.5), rinsed in distilled water, counterstained with nuclear fast red, dehydrated, and coverslipped with Permount (Fischer Scientific, Fairlawn, NJ, USA)

\section{RESULTS}

\section{PCR and Southern hybridizations}

Based on UV spectrophotometry, yields of extracted DNA were similar for pooled test and control paraffinembedded tissues and ranged from 70 to $140 \mathrm{ng} \mathrm{fl}^{-1}$. In PCR experiments performed at an annealing temperature of $55^{\circ} \mathrm{C}$, using DNA extracted from paraffinembedded test and control tissues and primers to the Atlantic salmon Bg/I element, there was amplification of DNA from all negative control samples as well as from representative samples of test and positive control tissues (Fig. 1), indicating that the extraction procedure was adequate for paraffin-embedded tissues

The $\mathrm{Bg} / \mathrm{I}$ repeat element is tandemly arrayed and located in the vicinity of the rRNA gene of the Salmo salar genome (Goodier \& Davidson 1993). According to 
Moran et al. (1997), at an annealing temperature of $62^{\circ} \mathrm{C}$, amplification of a portion of the $\mathrm{Bg} / \mathrm{I}$ element using the forward and reverse primers corresponding

$A$

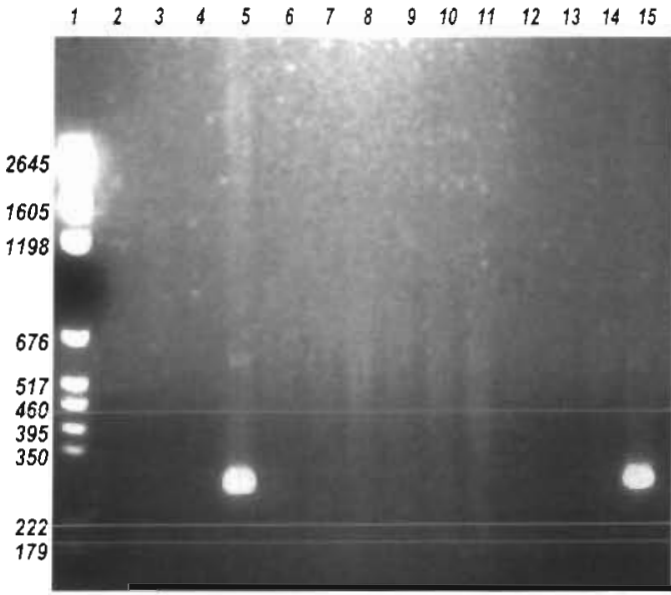

$B$

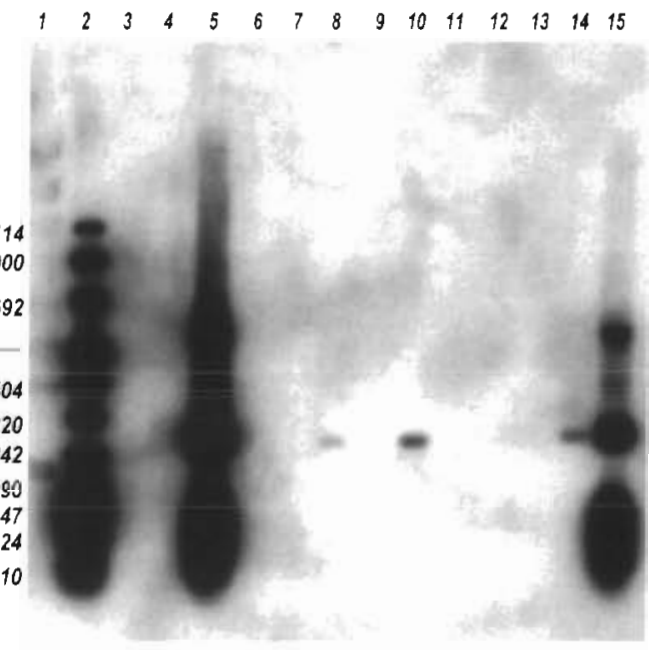

C $\begin{array}{llllllllllllllllll}1 & 2 & 3 & 4 & 5 & 6 & 7 & 8 & 9 & 10 & 11 & 12 & 13 & 14 & 15 & 16 & 17 & 18\end{array}$

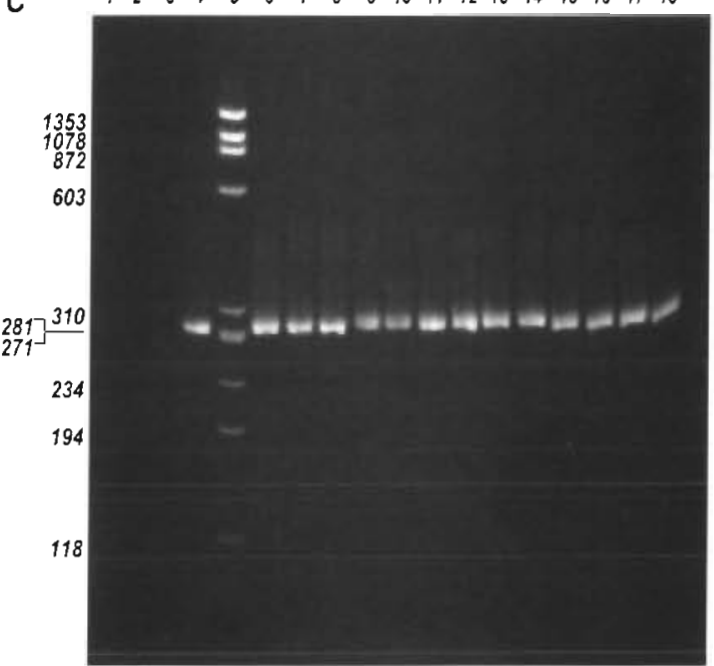

to positions 11 to 36 and 707 to 727 , respectively, generates fragments of 700 and 280 nucleotides in Atlantic salmon S. salar and 650 and 250 nucleotides in brown trout $S$. trutta. In this study, at an annealing temperature of $55^{\circ} \mathrm{C}$, uninfected control Atlantic salmon genomic DNA from paraffin-embedded brains fixed in 1997 yielded multiple amplicons, which included fragments of approximately 700,560, 290, 250, and 225 base pairs. DNA of myxosporean-infected Atlantic salmon from 1994 also yielded amplification products, although with less consistency than did the negative control DNA. DNA extractions from tissue sections from the same paraffin blocks of uninfected control Atlantic salmon brains from 1997 were repeated later in the study using the same protocol and yielded amplification products identical to those of the original negative control samples (Fig. 1). Oncorhynchus mykiss DNA from Myxobolus cerebralis-infected rainbow trout inconsistently yielded faint amplification products using the $S$. salar $\mathrm{Bg} / \mathrm{I}$ primers.

With few exceptions, the amplification products from samples of the Atlantic salmon myxosporean using each of the 5 primer pairs were not detectable in agarose gels, although the amplification products from Myxobolus cerebralis-infected rainbow trout tissue were visible (Fig. 2A). However, Southern hybridization with sequence-specific digoxigenin-labeled DNA

Fig. 2. Electrophoretic and Southern hybridization patterns of product 5636 ( 247 base pairs) amplified from formalin-fixed paraffin-embedded brain of Salmo salar using primers SM5-6 and SM3-6. (A) 2\% agarose gel electrophoresis of PCR products and (B) Southern blot of PCR products hybridized with digoxigenin-labeled double-stranded DNA probes created from the 5636 positive control amplification product. (A,B) Lane 1: pGEM molecular weight marker (Promega Corp.). Lane 2: digoxigenin-labeled DNA molecular weight marker VIII (Boehringer Mannheim Corp., Indianapolis, IN, USA). Lanes 3 and 4: genomic DNA from uninfected $S$. salar brain. Lanes 5 and 15: Oncorhynchus mykiss experimentally infected with Myxobolus cerebralis. Lanes 6 to 14: DNA from pooled extracts of $S$. salar brain infected with myxosporean developmental stages. Products in Lanes 6 to 14 are not detectable in the $2 \%$ agarose gel by ethidium bromide staining and UV trans-illumination, whereas those in Lanes 5 and 15 are visible. Hybridization with digoxigenin-labeled DNA probe reveals amplicons in Lanes 8,10 , and 14 with estimated lengths consistent with the $M$. cerebralis product at $<300$ and $>242$ base pairs. (C) Polyacrylamide gel electrophoresis ( $8 \%$ ) of purified products of second-round PCRs. (C) Lane 1: blank. Lane 2: reagent control. Lane 3: genomic DNA of uninfected S. salar. Lane 4: $M$. cerebralis-infected O. mykiss DNA. Lane 5: PhiX174 DNA/Hae III molecular weight marker (Promega Corp.). Lanes 6 to 18: DNA of myxosporeaninfected $S$. salar brains that yielded amplification products detectable by Southern hybridization. All second-round PCR products are the same size as that from $M$. cerebralis 
probes followed by chemiluminescent detection allowed for identification of PCR products that were not detectable by ethidium bromide staining and UV trans-illumination alone (Fig. 2B). Whenever extractions of DNA from Atlantic salmon infected with the myxosporean produced amplicons, those products were of the same molecular weight as amplicons from DNA of $M$. cerebralis-infected rainbow trout. The sizes of amplification products ranged from 187 to 287 base pairs for the different primer pairs (Table 1). DNA from $M$. cerebralis-infected rainbow trout consistently produced robust amplifications with each primer pair, whereas DNA extracted from Atlantic salmon smolts, which were determined by light microscopy to be free of myxosporeans, consistently failed to produce amplicons with any of the primer pairs.

Products of each primer pair were detectable by Southern hybridization using sequence-specific probes. The $5 \mu$ l samples from first-round PCR mixtures subjected to a second round of PCR yielded amplification products of sufficient concentration (i.e.

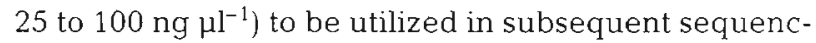
ing reactions. Purified second-round PCR products were detectable after electrophoresis in $8 \%$ polyacrylamide gels (Fig. 2C).

\section{Consensus sequences and sequence alignments}

A consensus sequence for the amplification product of each of the 5 different primer pairs was obtained from alignments of the forward and reverse sequencing reactions of a minimum of 5 separate PCR products. Overall, there was minimal variation in the sequences of the products of each primer pair with discrepancy between bases at less than $2 \%$ of the positions.

The consensus sequences of the 5 separate amplification products from the myxosporean were aligned with the SSU rDNA sequence of Myxobolus cerebralis (Fig, 3). Consensus sequences of products were consolidated at positions of overlap, resulting in a partial SSU rDNA sequence of the parasite consisting of a 5' fragment derived from products 5636 and 5335 , followed by a gap of undetermined bases, followed by a 3' fragment derived from products 5434, 5737 and 5838. This partial sequence was aligned with the SSU rDNA sequences of 3 neurotropic myxobolid parasites of salmonids, e.g. $M$. arcticus, $M$. cere-

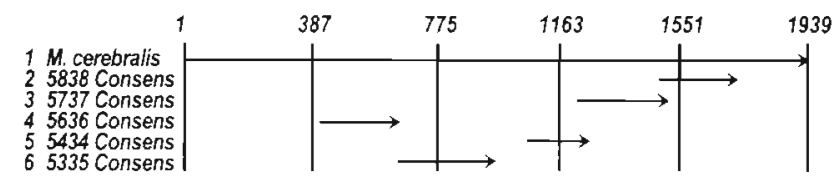

Fig. 3. Alignments of the SSU rDNA sequence of Myxobolus cerebralis (Row 1 ) with the consensus sequences of the 5 PCR products amplified from DNA of Salmo salar brains infected with myxosporean developmental stages (Rows 2 to 6 ). Note that products are identified by the numerical designations of the primers responsible for their amplification

bralis, and $M$. neurobius (Fig. 4). The reported bases of the Atlantic salmon myxosporean were identical to those of $M$. cerebralis at 78 of 81 locations of unmatched bases between the 4 sequences.

\section{Analysis of percent sequence identity}

Percent sequence identities between the SSU rDNA sequence of the parasite and regions of the SSU rRNA gene sequences of the myxosporeans of the study group were calculated separately for the 529-base pair and 661-base pair fragments and did not include the intervening gap of undetermined bases (Table 3). Both the 529-base pair and 661-base pair fragments were identical to relevant segments of the SSU rRNA gene sequence of Myxobolus cerebralis at $99 \%$ of their nucleotides, and both fragments shared more sequence identity (i.e. more identical nucleotides) with

Table 3. Percent sequence identity between the (a) 529-base pair and (b) 661 base pair fragments of the partial SSU rRNA gene sequence of the myxosporean from Atlantic salmon Salmo salar and known SSU rRNA gene sequences from a selection of myxosporeans (Myxobolus cerebralis, $M$. arcticus, $M$. neurobius, $M$. insidiosus, Henneguya doori, Ceratomyxa shasta and $M$. squamalis)

\begin{tabular}{|c|c|c|c|c|c|c|c|c|}
\hline (a) & 529-bp & M. cere & M. arc & M. neur & $M$. insid & H. door & - C. shast & M. squa \\
\hline 529-bp & 100 & 99.6 & 93.6 & 93.4 & 93.0 & 71.5 & 63.7 & 61.5 \\
\hline M. cere & & 100 & 93.2 & 93.0 & 92.7 & 71.1 & 63.8 & 58.0 \\
\hline M. arc & & & 100 & 98.7 & 97.6 & 71.1 & 64.6 & 60.3 \\
\hline M. neur & & & & 100 & 97.4 & 70.5 & 65.0 & 56.6 \\
\hline M. insid & & & & & 100 & 69.9 & 62.5 & 58.6 \\
\hline H. door & & & & & & 100 & 62.9 & 64.5 \\
\hline C. shast & & & & & & & 100 & 55.9 \\
\hline M. squa & & & & & & & & 100 \\
\hline (b) & $661-b p$ & M. cere & M. arc & M. neur & $M$. insid & H. door & C. shast & M. squa \\
\hline $661-b p$ & 100 & 99.4 & 89.5 & 91.5 & 89.3 & 85.4 & 80.7 & 75.1 \\
\hline M. cere & & 100 & 89.0 & 91.1 & 89.0 & 85.0 & 80.2 & 74.8 \\
\hline M. arc & & & 100 & 97.6 & 94.5 & 82.0 & 80.0 & 71.6 \\
\hline M. neur & & & & 100 & 96.5 & 83.7 & 80.5 & 72.5 \\
\hline M. insid & & & & & 100 & 82.7 & 80.5 & 70.9 \\
\hline H. door & & & & & & 100 & 77.7 & 80.9 \\
\hline C. shast & & & & & & & 100 & 82.1 \\
\hline M. squa & & & & & & & & 100 \\
\hline
\end{tabular}


M. cerebralia> M. neurobius M.arcticus

unknown cons

M. Cerebralis M. neurobius .arcticus

M. cerebralis M. neurobius Marcticus

M. cerebralis $M$. neurobius Marcticus

M. cerebralis> M. neurobius unknown cons

M. cerebralis> M. neurobius .arcticus

M. cerebralis M. neurobius M.arcticus $>$

M. cerebralis

M. cerebralis
M. neurobius M.arcticus unknown cons M. cerebralis M.arcticus
unknown cons?

M. cerebralis M. neurobius > M. arcticus

M. cerebraifa> M. cerebrails $>$ M.arcticus unknown cons?

M.cerebralis> M. neurobius Mnknown cons?

M.cerebralis M.neurobius > M.arcticus ?
unknown cons?

M.cerebralis>

M.cerebralis M.arcticus unknown cons?

M.cerebralis> . neurobius Marcticus >

M.cerebralis M. neurobius > M.arcticus >

M.cerebralis> M. cerebralis M.arcticus unknown cons?

M.cerebralis> M.neurobius Marcticus ?

M.cerebralis M. neurobius M.arcticus >

M. cerebralis> M. neurobius unknown cons?

M.cerebralis> M. neurobius > M.arcticus ?
unknown cons? 1 agatatacGC TtTTCtCTAa -89
$-89 \ldots \ldots \ldots \ldots$ $\ldots \ldots$

51 tagtaAaACG TGaGactgCo -39
-39 $\ldots \ldots \ldots$ $\ldots \ldots$

101 TGRTGTCTA 12 TGATTGTCTA CCCATTGGAT CCCATTGGAT CCCATTGGAT 160

151 CAGTTTTGG

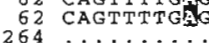

170 TAGCGT - AA NTAGCGT - AAA
ATAGCGT-AA 201210 201 CAACTACCG 112
-214
$-\ldots . .$.

260
251 AgATAACTTT
162 AGATACTTT 162 AAATAACTTT

301 A TTRCTGCCC 212 ATTRCTGCC

360 351 ATGGGTAACG 262 ACGGGTEACG 401 GGCTACCACA 312 GGCTACCACA 312 GGCTACCACA
$-14 \ldots \ldots \ldots .$.

460

451 ACACTGGG-A 362 ACACTGGGGA
37 ACACTGGG-A

5010 501 CCAGCTTGGA
412 CMAGCTGGA 412
87 CEAGCTTGGA

551 GGCAAGTCTG 462 GGCAAGTCTG

601 TTAAAGT 610 512 TTAAAGTTGC 187 TTAAAGTTGC

651 TGGTA 660

562 TGGTAAGCT

237 TGGTAGGCT
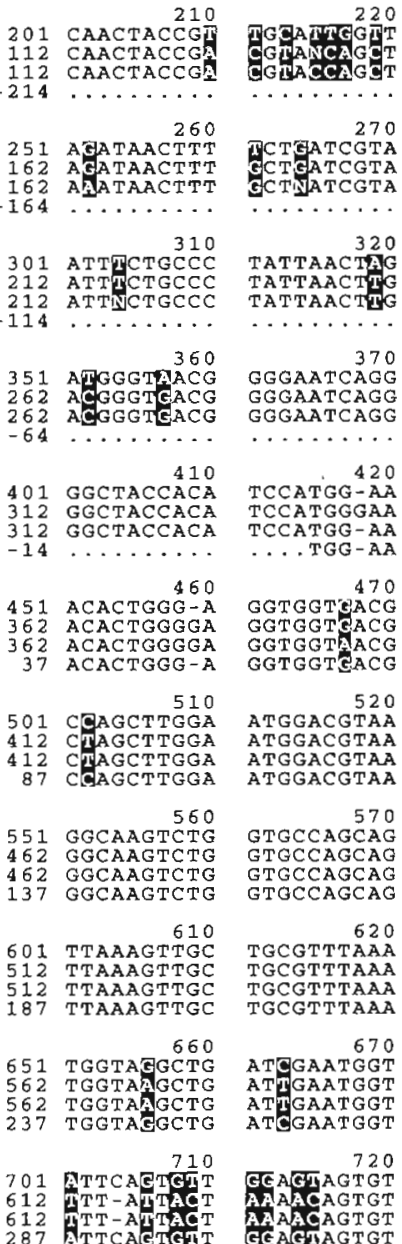
AGT

270 GCTATCGTA CTNATCGT

320

TATTAACTAG
TATTAACTTG
TATTAACTTG a toractég

370 GGGAATCAGG GGGAATCAGG

420
TCCATGG-AA
TCCATGGGAA TCCATGGGAA
TCCATGG-AA

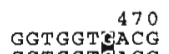

GGTGGTEACA GGTGGTHACG
GGTGGTSAC

ATGGACGTAA atgGacGTaA ATGGACGTAA
atgGaCGTAa

570 gTGCCAGCAG GTGCCAGCA

620

TECGTTTAAA TGCGTTTAAA TGCGTTtAaA

670
ATMGAATGGT
ATUGATGGT ATEA
ATMGATGGGT
ATGGAATGG

720
GEAGMAGTGT
AHAACAGTGT AAAAAGTGT
AAAAGTGT
GEAEMAGTGT

751 TACTTACGC

662 TACTTACGCG

662
337 TACTTACGCG

801 - CTTACGGAG

712 - CTTACGGAG

-

851 CTTGAATET

762 CTTGAATATT

437 CTTGAATETT

901 CAAATAGCGA 812 CACATAGCGA 812
487 CAAATAGCGA

951 CACCAACCAC 862 CACCAACCAC 862 CACCAACCAC
537 ?????????

001 AGGAGCGGT 912 AGGAGCGGTT
912 AGGAGCGGTT
587 ??????????

TAAGGATGG TAAGGATGGC TAAGGATGGC

820

TGTGCCTTGA TGTGCCTTGA TGTGCCTTGA

AATAGCATGO AATAGCATG AATAGCATGE

920
TCGGMCTTTG
TCGGTCTTTG TCGGNCTTTG

CAATAACGGA CAATAACGG ?????????? 1020 GGGGGCATT GGGGGCATTG GGG??????

GACTAAGCCA $\ldots \ldots$ $\ldots \ldots \ldots$

GACGGCTCAG

TAAATCAGT 90 $\ldots \ldots \ldots$ T

AAATCTAGAG AACCNNAGGE AACCOTGGG

....... AAATCTAGA

A $C$

AGTCTCTCA -TGTCTCA 230
TACGCTGATG
T--GCTGLTG
T--GCTGATG

280
TGG-CCTAMA T-GGCCTAdT ........

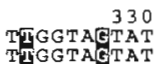
TTGGTAGTAT
TEGGTATAT

380
GTTCGATTCC GTTCGATCC

430

GGCAGCAGGC GGCAGCAGGC GCAGCAGGC

$\begin{array}{r}480 \\ \text { AGAAGTACTA } \\ \hline\end{array}$ ANAAGTACTA AGAAGTACTA

530
TTTAAGTAAT TTTAAGTAAT TTTAAGTAAT
TTTAATAAT

580

CCGCGGTAAT CCGCGGTAAT 630

ACGCTCGTAG ACGCTCGTAG ACGCTCGTAG

190
CGGCATTTAT CGGCATTTAT 240
TAA GCGAGTA
CGA CGCGTA 290
GCCGGCCAC'
GCCGGCGNCN
GCCGGCAACG .........

\section{AGAAGCCTAC} A GTTGCCTAC
AWrGGCTAC

390 GGAGAGGGA GGAGAGGGAG

440 GCGCAAATTA GCGCAAATTA GCGCAARTTA

490
AGTGGTGCC AGTGGTGGCC AGTGGTGGCC

540 TCGATGAGTA TCGATGAGTA
TCGATGATA

TCCAGCTCCA TCCAGCTCC

TCCAGCTCCA 640

TTGGATCACG TTGGATCACG TTGGATCACG

680
GCTACTAACT GCTCC-AACT GCTCC-AACI
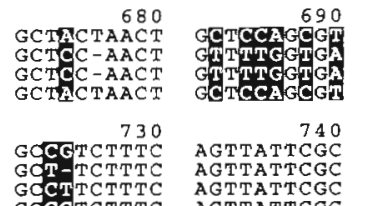

AGTTATTCGC AGTTATTCGC AGTTATTCGC

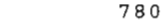

TA

AGTTGACCTT AGTTGACCTT
AGTTGACCTT

830
ATAAATCAGa ATAAATCAGA
ATAAATCAGA ATAAATCAga 880

AACGATIAAT AACGAGGAAT
AACGAACAAT AACGABCAAT

930
ACTGAATGTT aCTGAaTget ACTgAaTgeT TAGTGCGTCG TAGTGCGTCG

840
GTGCTCAAAG GTGCTCAAAG GTGCTCAAAG 890 TGTGTAGTAG TGTGTAGTAG 


\begin{tabular}{|c|c|c|c|c|c|c|c|}
\hline $\begin{array}{l}\text { M.cerebralis> } \\
\text { M.neurobius > } \\
\text { M.arcticus > } \\
\text { unknown cons> }\end{array}$ & $\begin{array}{r}1051 \\
962 \\
962 \\
637\end{array}$ & $\begin{array}{r}1060 \\
\text { ACCGGCCAAG } \\
\text { ACCGGCCAAG } \\
\text { ACCGGCCAAG } \\
? ? ? ? ? ? ? ? ?\end{array}$ & $\begin{array}{l}1070 \\
\text { GACTAACGAA } \\
\text { GACTAACGAA } \\
\text { GACTAACGAA } \\
\text { ????????? }\end{array}$ & $\begin{array}{l}1080 \\
\text { TGCGAAGGCA } \\
\text { TGCGAAGGCA } \\
\text { TGCGAAGGCA } \\
\text { ????????CA }\end{array}$ & $\begin{array}{r}1090 \\
\text { TTTGECEAGA } \\
\text { TTTGACTAGA } \\
\text { TTTGTCTAGA } \\
\text { TTTGCCCAGA }\end{array}$ & $\begin{array}{r}1100 \\
\text { CCGGCTCGCT } \\
\text { CCGCCTCGCT } \\
\text { CCGCNTCGCT } \\
\text { CCGCCTCGCT }\end{array}$ & 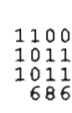 \\
\hline $\begin{array}{l}\text { M.cerebraliss } \\
\text { M.neurobius } \\
\text { M.arcticus > } \\
\text { unknown cons> }\end{array}$ & $\begin{array}{r}1101 \\
1012 \\
1012 \\
687\end{array}$ & $\begin{array}{l}1110 \\
\text { TAATCAAGAA } \\
\text { TAATCAAGAA } \\
\text { TAATCAAGAA } \\
\text { TAATCAAGAA }\end{array}$ & $\begin{array}{l}1120 \\
\text { CGATAGTGG- } \\
\text { CGATAGTGGG } \\
\text { CGATAGTGGG } \\
\text { CGATAGTGGG }\end{array}$ & $\begin{array}{l}1130 \\
\text { AGGTTCGAAG } \\
\text { AGGTTCGAAG } \\
\text { AGGTTCGAAG } \\
\text { AGGTTCGAAG }\end{array}$ & $\begin{array}{l}1140 \\
\text { ACGATCAGAT } \\
\text { ACGATCAGAT } \\
\text { ACGATCAGAT } \\
\text { ACGATCAGAT }\end{array}$ & $\begin{array}{l}1150 \\
\text { ACCGTCCTAG } \\
\text { ACCGTCCTAG } \\
\text { ACCGTCCTAG } \\
\text { ACCGTCCTAG }\end{array}$ & 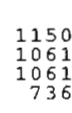 \\
\hline $\begin{array}{l}\text { M.cerebralis> } \\
\text { M.neurobius > } \\
\text { M.arcticus > } \\
\text { unknown cons> }\end{array}$ & $\begin{array}{r}1151 \\
1062 \\
1062 \\
737\end{array}$ & $\begin{array}{r}1160 \\
\text { TTCCCACTGT } \\
\text { TTCCCACTGT } \\
\text { TTCCCACTGT } \\
\text { TTCCCACTGT }\end{array}$ & $\begin{array}{r}1170 \\
\text { AAACTATGCC } \\
\text { AAACTATGCC } \\
\text { AAACTATGCC } \\
\text { AAACTATGCC }\end{array}$ & $\begin{array}{r}1180 \\
\text { GACCCGGGAT } \\
\text { GACCCGGGAT } \\
\text { GACCCGGGAT } \\
\text { GACCCGGGAT }\end{array}$ & $\begin{array}{r}1190 \\
\text { CAGCATGAAG } \\
\text { CAGCATGAAG } \\
\text { CAGCATGAAG } \\
\text { CAGCATGAAG }\end{array}$ & $\begin{array}{r}1200 \\
\text { CTCTMTATAC } \\
\text { CTCTATATAT } \\
\text { TCTATATAT } \\
\text { CTCTTATAC }\end{array}$ & 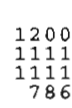 \\
\hline $\begin{array}{l}\text { M.cerebralis> } \\
\text { M.neurobius > } \\
\text { M.arcticus > } \\
\text { unknown cons> }\end{array}$ & $\begin{array}{r}1201 \\
1112 \\
1112 \\
787\end{array}$ & $\begin{array}{r}1210 \\
\text { GCTTATATT } \\
\text { GCTTGATGTT } \\
\text { GCTTGATGTT } \\
\text { GCTTATGTT }\end{array}$ & $\begin{array}{l}1220 \\
\text { GGयCCCCTG } \\
\text { GGHCCCCCTG } \\
\text { GGACCCCCTG } \\
\text { GGUCCCCCTG }\end{array}$ & $\begin{array}{r}1230 \\
\text { GGAAACCTCA } \\
\text { GGAAACCTCA } \\
\text { GGAAACCTCA } \\
\text { GGAAACCTCA }\end{array}$ & $\begin{array}{r}1240 \\
\text { AGTTTTCGG } \\
\text { AGTTTTTCGG } \\
\text { AGTTTTCGG } \\
\text { AGTTTTTCGG }\end{array}$ & $\begin{array}{r}1250 \\
\text { TTACGGGGAG } \\
\text { TTACGGGGA } \\
\text { TTACGGGGAG } \\
\text { TTACGGGGAG }\end{array}$ & $\begin{aligned} 1250 \\
1161 \\
1161 \\
836\end{aligned}$ \\
\hline $\begin{array}{l}\text { M.cerebraliss } \\
\text { M.neurobius > } \\
\text { M.arcticus > } \\
\text { unknown cons> }\end{array}$ & $\begin{array}{r}1251 \\
1162 \\
1162 \\
837\end{array}$ & $\begin{array}{r}1250 \\
\text { AGTATGGTCA } \\
\text { AGTATGGTCG } \\
\text { AGTATGGTCG } \\
\text { AGTATGGTCG }\end{array}$ & $\begin{array}{r}1270 \\
\text { CAAGGCTGAA } \\
\text { CAAGGCTGAA } \\
\text { CAAGGCTGAA } \\
\text { CAAGGCTGAA }\end{array}$ & $\begin{array}{r}1280 \\
\text { ACTTAAAGGA } \\
\text { ACTTAAAGGA } \\
\text { ACTTAAAGGA } \\
\text { ACTTAAAGGA }\end{array}$ & $\begin{array}{l}1290 \\
\text { ATTGACGGAA } \\
\text { ATTGACGGAA } \\
\text { ATTGACGGAA } \\
\text { ATTGACGGAA }\end{array}$ & $\begin{array}{r}1300 \\
\text { GGGCACCACC } \\
\text { GGGCACCACC } \\
\text { GGGCACCACC } \\
\text { GGGCACCACC }\end{array}$ & $\begin{array}{r}1300 \\
1211 \\
1211 \\
886\end{array}$ \\
\hline $\begin{array}{l}\text { M.cerebraliss } \\
\text { M.neurobius > } \\
\text { M.arcticus > } \\
\text { unknown cons> }\end{array}$ & $\begin{array}{rl}13 & 01 \\
1212 \\
1212 \\
887\end{array}$ & $\begin{array}{r}1310 \\
\text { AGGAGTGGAG } \\
\text { AGGAGTGGG } \\
\text { AGGAGTGGAG } \\
\text { AGGAGTGGAG }\end{array}$ & $\begin{array}{r}1320 \\
\text { CCTGCGGCTT } \\
\text { CCTGCGGCTT } \\
\text { CCTGCGGCTT } \\
\text { CCTGCGGCTT }\end{array}$ & $\begin{array}{r}1330 \\
\text { AATTTGACTC } \\
\text { AATTTGACTC } \\
\text { AATTTAATC } \\
\text { AATTTGACTC }\end{array}$ & $\begin{array}{r}1340 \\
\text { AACACGGGAA } \\
\text { AACACGGGAA } \\
\text { AACACGGGAA } \\
\text { AACACGGGAA }\end{array}$ & $\begin{array}{l}1350 \\
\text { AACTTACCAG } \\
\text { AACTTACCAG } \\
\text { AACTTACCAG } \\
\text { AACTTACCAG }\end{array}$ & $\begin{array}{r}1350 \\
1261 \\
1261 \\
936\end{array}$ \\
\hline $\begin{array}{l}\text { M.cerebralis> } \\
\text { M.neurobius > } \\
\text { M.arcticus > } \\
\text { unknown cons> }\end{array}$ & $\begin{array}{r}1351 \\
1262 \\
1262 \\
937\end{array}$ & $\begin{array}{r}1360 \\
\text { GTCCGGACAT } \\
\text { GTCCGGACAT } \\
\text { GTCCGGACAT } \\
\text { GTCCGGACAT }\end{array}$ & $\begin{array}{r}1370 \\
\text { CAATAGGATA } \\
\text { CAATAGGTA } \\
\text { CAATAGGATA } \\
\text { CAATAGGATA }\end{array}$ & $\begin{array}{r}1380 \\
\text { GACAAGACTG } \\
\text { GACA-GACTG } \\
\text { GACA-GACTG } \\
\text { GACA-GACTG }\end{array}$ & $\begin{array}{r}1390 \\
\text { ATAGATCTTT } \\
\text { ATAGATCTTT } \\
\text { ATAGATCTTT } \\
\text { ATAGATCTTT }\end{array}$ & $\begin{array}{r}1400 \\
\text { - CTTGATATG } \\
\text { TCTTGATATG } \\
\text {-CTTGATATG } \\
\text { - CTTGATATG }\end{array}$ & $\begin{array}{r}1400 \\
1311 \\
1311 \\
986\end{array}$ \\
\hline $\begin{array}{l}\text { M.cerebralis> } \\
\text { M.neurobius > } \\
\text { M.arcticus > } \\
\text { unknown cons> }\end{array}$ & $\begin{array}{rl}14 & 01 \\
1312 \\
1312 \\
987\end{array}$ & $\begin{array}{r}1410 \\
\text { ATGGATAGT } \\
\text { ATGGATAGT } \\
\text { ATGGATAGTG } \\
\text { ATGGATAGTG }\end{array}$ & $\begin{array}{r}1420 \\
\text { GTGCATGGCC } \\
\text { GTGCATGGCC } \\
\text { GTGCATG-CC } \\
\text { GTGCATGGCC }\end{array}$ & $\begin{array}{r}1430 \\
\text { GTTCTTAGTT } \\
\text { GTTCTTAGT } \\
\text { GTT-TTAGTT } \\
\text { GTTCTTAGTT }\end{array}$ & $\begin{array}{r}1440 \\
\text { CGTGGAGTGA } \\
\text { CGTGGATGA } \\
\text { CGTGG-GTGA } \\
\text { CGTGGAGTGA }\end{array}$ & $\begin{array}{l}1450 \\
\text { TCTGTCAGGC } \\
\text { TCTGTCAGGC } \\
\text { TCTGTCAGG- } \\
\text { TCTGTCAGGC }\end{array}$ & $\begin{array}{l}1450 \\
1361 \\
1361 \\
1036\end{array}$ \\
\hline $\begin{array}{l}\text { M.cerebraliss } \\
\text { M. neurobius } \\
\text { M.arcticus > } \\
\text { unknown conss }\end{array}$ & $\begin{array}{l}1451 \\
1362 \\
1362 \\
1037\end{array}$ & $\begin{array}{r}1460 \\
\text { TAATCCCGGT } \\
\text { TAATCCCGT } \\
\text { TAATCCCGGT } \\
\text { TAATCCCGGT }\end{array}$ & $\begin{array}{r}1470 \\
\text { AACG-AACGA } \\
\text { AACG-AACGA } \\
\text { AACGGAACGA } \\
\text { AACG-AACGA }\end{array}$ & $\begin{array}{r}1480 \\
\text { GATCTTATC } \\
\text { GAMCTTATC } \\
\text { GAATTATTC } \\
\text { GADCTTATTC }\end{array}$ & $\begin{array}{r}1490 \\
\text { TCCATTTGAT } \\
\text { TCCATTTGAT } \\
\text { TCCATTTGAT } \\
\text { TCCATTTGAT }\end{array}$ & $\begin{array}{r}1500 \\
\text { GAGCGGAAGM } \\
\text { GAGCGGAAGC } \\
\text { GAGCGGAAGC } \\
\text { GAGCGGAAGA }\end{array}$ & $\begin{array}{l}1500 \\
1411 \\
1411 \\
1086\end{array}$ \\
\hline $\begin{array}{l}\text { M.cerebralis } \\
\text { M.neurobius } \\
\text { M.arcticus > } \\
\text { unknown cons? }\end{array}$ & $\begin{array}{l}1501 \\
1412 \\
1412 \\
1087\end{array}$ & $\begin{array}{l}1510 \\
\text { AGATAGTGA } \\
\text { AGATGGT-- } \\
\text { AGATGGG-- } \\
\text { AGATAGTGTA }\end{array}$ & $\begin{array}{r}1520 \\
\text { GCTCGATAT } \\
\text { GCTMGAAA } \\
\text { GCTMGAAAAT } \\
\text { GCTGGAMAAT }\end{array}$ & $\begin{array}{r}1530 \\
\text { TGIMTCGGCG } \\
\text { TGTCTCGATG } \\
\text { TGTCTCGATG } \\
\text { TGTLTCGECG }\end{array}$ & $\begin{array}{r}1540 \\
\text { AT-TCTCAAG } \\
\text { ATAT-TCAAG } \\
\text { AAAT-TCAAG } \\
\text { AT-TCTCAAG }\end{array}$ & $\begin{array}{r}1550 \\
\text { TTALTCTATC } \\
\text { TTAM-C-ATC } \\
\text { TTAN-C-ATC } \\
\text { TTATCTATC }\end{array}$ & $\begin{array}{l}1550 \\
1461 \\
1461 \\
1136\end{array}$ \\
\hline $\begin{array}{l}\text { M.cerebraliss } \\
\text { M.neurobius > } \\
\text { M.arcticus > } \\
\text { unknown cons> }\end{array}$ & $\begin{array}{l}1551 \\
1462 \\
1462 \\
1137\end{array}$ & $\begin{array}{r}1560 \\
\text { GTAGGCAGTG } \\
\text { GAAGGCAGT } \\
\text { GAAGGCAGTG } \\
\text { GRAGGCAGTG }\end{array}$ & $\begin{array}{r}1570 \\
\text { TTGMGATT } \\
\text { CTGGGATT } \\
\text { CTTGCGAGTT } \\
\text { TTGGAATT }\end{array}$ & $\begin{array}{r}1580 \\
\text { TAETGT-GAA } \\
\text { TATTGTTAA } \\
\text { TATTGTTAAA } \\
\text { TAGTGT-GAA }\end{array}$ & $\begin{array}{l}1590 \\
\text { A-ATACAGUT } \\
\text { ATATAAAGA- } \\
\text { ATATAAAGA- } \\
\text { A-ATACAGHT }\end{array}$ & $\begin{array}{r}1600 \\
\text { TGTTGCGAG } \\
\text {-GTTGCGAAA } \\
\text {-GTTGCGAGA } \\
\text { TGTTGCGAGG }\end{array}$ & $\begin{array}{l}1600 \\
1511 \\
1511 \\
1186\end{array}$ \\
\hline $\begin{array}{l}\text { M.cerebralis> } \\
\text { M.neurobius } \\
\text { M.arcticus > } \\
\text { unknown conss }\end{array}$ & $\begin{array}{l}1601 \\
1512 \\
1512 \\
1187\end{array}$ & $\begin{array}{l}1610 \\
\text { ACGGGATAAA } \\
\text { ACGGTCTTAA } \\
\text { ACGGACTTAA } \\
\text { ACGGGATIAA }\end{array}$ & $\begin{array}{r}1620 \\
\text { ACTC-TTACT } \\
\text { CCCATT-CT } \\
\text { CCCATT-CT } \\
\text { ACTC-TTACT }\end{array}$ & 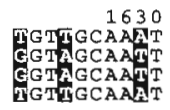 & $\begin{array}{r}1640 \\
\text { TGTACTACA } \\
\text { TGTACTAAAT } \\
\text { TGTACTAAAT } \\
\text { TGTACTACAC }\end{array}$ & $\begin{array}{r}1650 \\
\text { CTEAETTTT } \\
\text { GTAAATTGT } \\
\text { GTAATTTGT } \\
\text { GTEATTTGT }\end{array}$ & $\begin{array}{l}1650 \\
1561 \\
1561 \\
1236\end{array}$ \\
\hline $\begin{array}{l}\text { M.cerebralis> } \\
\text { M.neurobius > } \\
\text { M.arcticus } \\
\text { unknown cons> }\end{array}$ & $\begin{array}{l}1651 \\
1562 \\
1562 \\
1237\end{array}$ & $\begin{array}{l}1660 \\
\text { TGGCATTCCC } \\
\text { TGGCATMCCC } \\
\text { TGGCATNCCC } \\
\text { TGGCATUCCC }\end{array}$ & $\begin{array}{l}1670 \\
\text { TTCCGTTATA } \\
\text { TTCCGTATA } \\
\text { TTCCGTTATA } \\
\text { TTCCGTTATA }\end{array}$ & $\begin{array}{r}1680 \\
\text { CGCTGTTCAA } \\
\text { CGCTGTTCTA } \\
\text { CGCTGTNCTA } \\
\text { CGCTGTWCAA }\end{array}$ & $\begin{array}{l}1690 \\
\text { CT-ACCGA-G } \\
\text { CTTACCAAAG } \\
\text { CTTACDAAAG } \\
\text { CT-ACCCA-G }\end{array}$ & $\begin{array}{r}1700 \\
\text { TTGAGCAGT } \\
\text { TEGAGCAGTG } \\
\text { TGGAGCAGTG } \\
\text { TUGAGCAGTG }\end{array}$ & $\begin{array}{llll}1 & 7 & 0 & 0 \\
1 & 6 & 1 & 1 \\
1 & 51 & 1 \\
1 & 2 & 8 & 6\end{array}$ \\
\hline $\begin{array}{l}\text { M.cerebraliss } \\
\text { M.neurobius } \\
\text { M.arcticus } \\
\text { unknown cons> }\end{array}$ & $\begin{array}{l}1701 \\
1612 \\
1612 \\
1287\end{array}$ & $\begin{array}{r}1710 \\
\text { TGTCATGGAG } \\
\text { TGTCATGGA } \\
\text { TGTCATGGAG } \\
\text { TGTCATGGAG }\end{array}$ & $\begin{array}{r}1720 \\
\text { AGACTGTGAG } \\
\text { AGACTGTGAG } \\
\text { AGACTGTGAG } \\
\text { AGACTGTGAG }\end{array}$ & $\begin{array}{r}1730 \\
\text { GTATATATCC } \\
\text { G... } \\
\text { GTATATATCC } \\
\text { GTATA }\end{array}$ & $\begin{array}{r}1740 \\
\text { AAGCTCAATG } \\
\cdots \cdots \\
\text { AAGCTCAATG }\end{array}$ & $\begin{array}{r}1750 \\
\text { AAGCAAGGCC } \\
\therefore \because \cdots \\
\text { ACGCAAG } .\end{array}$ & $\begin{array}{l}1750 \\
1661 \\
1661 \\
1336\end{array}$ \\
\hline $\begin{array}{l}\text { M.cerebralis } \\
\text { M.neurobius } \\
\text { M.arcticus } \\
\text { unknown conss }\end{array}$ & $\begin{array}{l}1751 \\
1662 \\
1662 \\
1337\end{array}$ & 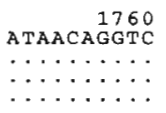 & 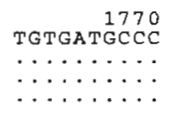 & 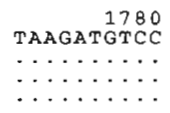 & 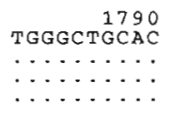 & 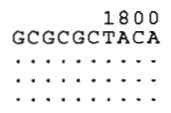 & $\begin{array}{l}1800 \\
1711 \\
1711 \\
1386\end{array}$ \\
\hline $\begin{array}{l}\text { M. cerebralis> } \\
\text { M.neurobius > } \\
\text { M.arcticus > } \\
\text { unknown cons> }\end{array}$ & $\begin{array}{l}1801 \\
1712 \\
1712 \\
1387\end{array}$ & $\begin{array}{l}\text { ATGATGGTGA } \\
1810 \\
\therefore \cdots \cdots \\
\therefore \ldots\end{array}$ & 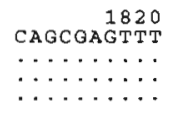 & 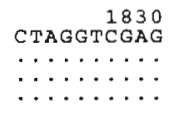 & 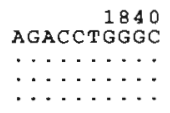 & 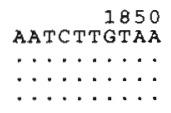 & $\begin{array}{l}1850 \\
1761 \\
1761 \\
1436\end{array}$ \\
\hline $\begin{array}{l}\text { M. cerebralis } \\
\text { M.neurabius } \\
\text { M.arcticus } \\
\text { unknown conss }\end{array}$ & $\begin{array}{l}1851 \\
1762 \\
1762 \\
1437\end{array}$ & 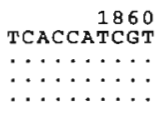 & 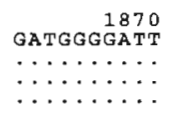 & 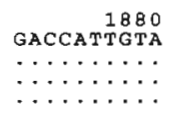 & 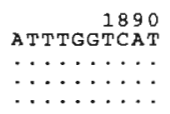 & $\begin{array}{l}\begin{array}{r}1900 \\
\text { GAAATAGGAA }\end{array} \\
\cdots \cdots \cdots \cdots \\
\cdots \cdots \cdots\end{array}$ & $\begin{array}{llll}1 & 9 & 0 & 0 \\
1 & 81 & 1 \\
1 & 81 & 1 \\
14 & 486\end{array}$ \\
\hline $\begin{array}{l}\text { M. cerebralis } \\
\text { M.neurobius > } \\
\text { M.arcticus > } \\
\text { unknown cons> }\end{array}$ & $\begin{array}{l}1901 \\
1812 \\
1812 \\
1487\end{array}$ & 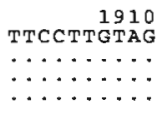 & 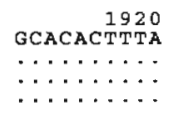 & 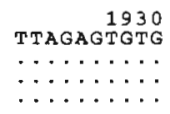 & 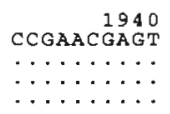 & 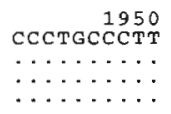 & $\begin{array}{l}1950 \\
1861 \\
1861 \\
1536\end{array}$ \\
\hline $\begin{array}{l}\text { M.cerebralis> } \\
\text { M.neurobius > } \\
\text { M.arcticus > } \\
\text { unknown cons> }\end{array}$ & $\begin{array}{l}1951 \\
1862 \\
1862 \\
1537\end{array}$ & \begin{tabular}{l} 
TGTA. \\
$\cdots \cdots$ \\
\hdashline$\ldots$ \\
\hdashline$\ldots$
\end{tabular} & $\begin{array}{l}1 \\
\ldots \ldots \\
\cdots \cdots \\
\ldots \ldots\end{array}$ & \begin{tabular}{l}
\multicolumn{1}{c}{1980} \\
$\because \ldots \ldots \cdots$ \\
$\therefore \ldots \cdots$
\end{tabular} & $\begin{array}{l}1990 \\
\ldots \\
\ldots \\
\ldots\end{array}$ & $\begin{array}{l}2000 \\
\ldots \ldots \\
\cdots \cdots \\
\cdots \cdots\end{array}$ & $\begin{array}{l}2000 \\
1911 \\
1911 \\
1586\end{array}$ \\
\hline
\end{tabular}

Fig. 4. Alignments of the partial SSU rDNA sequence of the myxosporean (unknown cons) from Salmo salar brains with the SSU rDNA sequences of 3 neurotropic myxobolids: Myxobolus cerebralis, $M$. neurobius, and $M$. arcticus. Note that unmatched bases are highlighted. -: base position not reported; $N$ : undetermined base, possibly $A, T, C$, or $G$; ?: base position not sequenced 
sequences from neurotropic and myotropic Myxobolus species than with those from epitheliotropic species of Myxobolus and Henneguya or an enterotropic species of Ceratomyxa. For all the myxosporeans of the study group, there was more sequence identity over the 661 base pair region than the 529-base pair region. With the exception of $M$. squamalis, the 529-base pair fragment from the parasite demonstrated more sequence identity with sequences from species of Myxobolus than with sequences from Henneguya doori or Ceratomyxa shasta.

\section{In situ hybridization}

Digoxigenin-labeled DNA probes complementary to segments of the SSU IRNA gene of Myxobolus cerebralis hybridized with DNA of the parasite in histologic sections of formalin-fixed Atlantic salmon brains. Probes hybridized with trophozoites and spores of $M$. cerebralis in histologic sections of rainbow trout fingerlings, whereas no hybridization signal was detectable in serial histologic sections processed without probes (i.e. negative probe control) (Fig. 5A,B). Probes which

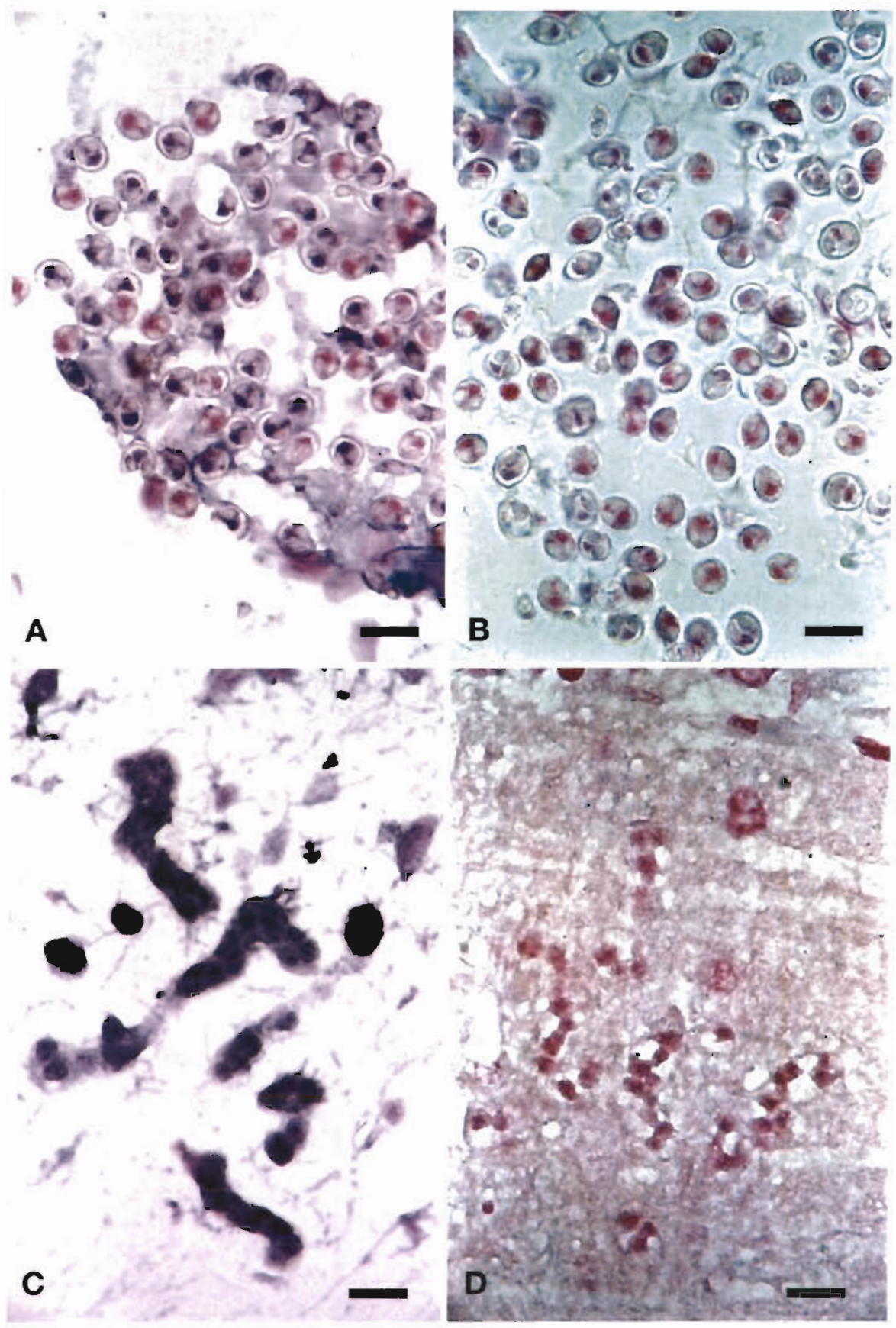

Fig. 5. In situ hybridization (ISH) of the myxosporean of Salmo salar in histologic sections of formalin-fixed paraffin-embedded brains of smolts from 1994, using Myxobolus cerebralis SSU rDNA sequence-specific digoxigenin-labeled single-stranded oligonucleotide DNA probes. (A) Positive (i.e. blue) labeling of sporoplasms of spores of $M$. cerebralis in a histologic section from an experimentally infected rainbow trout Oncorhynchus mykiss fingerling and (B) similar section, processed for ISH using hybridization solution lacking probes (i.e. negative probe control). Sporoplasms stain only with the red counterstain. (C) Positive labeling of the myxosporean in a histologic section of Atlantic salmon brain from a 1994 smolt using the probes that hybridized with spores of $M$. cerebralis in (A); and (D) similar section, processed for ISH using hybridization solution lacking probes (i.e. negative probe control). Parasites stain only with the red counterstain. Stains: Nitro blue tetrazolium chloride and nuclear fast red. Scale bars $=10 \mu \mathrm{m}$ 
hybridized with DNA of $M$. cerebralis also hybridized with DNA of the myxosporean in histologic sections of Atlantic salmon brains from 1994 (Fig. 5C,D). There was no hybridization in histologic sections of uninfected Atlantic salmon brains from 1997.

When compared to consensus sequences of PCR products from the myxosporean, sequences of the in situ probes were complementary to regions within the sequences of products 5335 (i.e. Tr3-17) and 5838 (i.e. $\operatorname{Tr} 3-16$ ). Probe Tr5-16 was located in a region of the $M$. cerebralis SSU rRNA gene $5^{\prime}$ to the segment complementary to product 5636 .

\section{DISCUSSION}

\section{Polymerase chain reaction and hybridization experiments}

The amplification and hybridization of DNA from formalin-fixed paraffin-embedded salmonid tissues in this study are consistent with previous findings using human tissue samples (Impraim et al. 1987). Inconsistent amplification of DNA from samples containing the myxosporean parasite may be related to factors such as the absence or paucity of target DNA in small tissue samples, the co-purification of biochemical compounds inhibitory to enzymatic reactions, and the degradation of target DNA by fixation and extraction, each of which has been known to compromise efficient PCR amplification of DNA from formalin-fixed paraffin-embedded human tissue samples (Merkelbach et al. 1997).

Myxosporean proliferative stages, such as the solitary cells, cell doublets, or multicellular stages of Myxobolus cerebralis (El-Matbouli et al. 1995), or the multicellular blood-borne stages of Sphaerospora renicola (Molnár 1993), often occur in small numbers and are widely dispersed within host tissues, making capture of their DNA difficult. In order to enrich test samples for PCR with target DNA from the parasite, brains from the 1994 epizootic were used in preference to those from the 1995 study, as the former had an increased prevalence and density of infection; tissue sections with a high probability of containing parasite foci were pooled by first examining preceding tissue sections for the presence of the parasite.

Co-purification of residual protein and membrane components contribute to weak or absent amplification signals by inhibiting Taq polymerase activity (Jackson et al. 1991, Merkelbach et al. 1997) and may have contributed to the weak amplification signals from experimental samples in this study. The QIAamp DNA extraction system was employed because of its ability to reduce the concentration of inhibitory compounds in extracted DNA, to yield DNA fragments of higher average length, and to yield higher amounts of DNA as compared to other methods of DNA purification (Merkelbach et al. 1997).

Degradation of target DNA by fixation is the most significant problem in molecular analysis of DNA extracted from paraffin blocks (Mies et al. 1991). Breakpoints in the linear series of bases in DNA prevent oligonucleotide-directed enzymatic amplification of DNA despite primer annealing in the context of an appropriately optimized PCR reagent mixture, thus leading to the occurrence of false negative amplification results (Mies 1994). However, partially degraded low molecular weight DNA from formalin-fixed paraffin-embedded tissue can serve adequately in PCR, provided that yields of DNA from extraction techniques are sufficient and that primer strategies target smaller regions of DNA for amplification (Honma et al. 1993, Mies 1994). Initial attempts at PCR in this study were unsuccessful using primers designed to amplify an 858-base pair fragment of the myxosporean SSU rDNA in either single-round or nested protocols (data not shown). Based on these findings and to compensate for the low molecular weight DNA from the Atlantic salmon brains (some of which had been stored for $>3$ yr in formalin before being embedded in paraffin), primer pairs were constructed to amplify regions of SSU rDNA in the range of 100 to 500 base pairs. Productive primers in this study generated amplicons that ranged in length from 187 to 287 base pairs.

Detection of amplification products by hybridization with sequence-specific probes confirmed the sequence identity of amplicons with those of SSU rDNA from Myxobolus cerebralis, and further in situ hybridization (ISH) experiments confirmed that the template DNA for these products was derived from the myxosporean identified in histologic sections of infected Atlantic salmon brains. In situ hybridization can detect which cells of a mixed population within a tissue possess a specific nucleic acid sequence (Crabbe et al. 1992), thereby increasing the resolution of sequence recognition from that of the entire tissue, as determined by Southern hybridization, to that of the cellular or subcellular compartment (Gan et al. 1994). M. cerebralis SSU rDNA sequence-specific DNA probes hybridized with DNA of cells within multicellular developmental stages of the parasite. Such hybridizations are consistent with the high percent sequence identity determined to exist between amplification products from the myxosporean and the $M$. cerebralis SSU rRNA gene, and they establish the myxosporean as the most probable source of template DNA for PCR products using primers derived from the SSU rDNA sequence of $M$. cerebralis.

In accord with the findings of Antonio et al. (1998), the labeling of Myxobolus cerebralis trophozoites in our ISH experiments was more consistent than that 
of spores, owing to the fact that spores were more resistent to protease digestion (Antonio et al. 1998). Similarly, ISH I involving myxosporean-infected Atlantic salmon brains from 1994 required longer protease digestion times to counter the extensive cross-linking of proteins caused by prolonged formalin fixation, which can significantly limit hybridization signals (Guiot \& Rahier 1995).

\section{Sequence alignments and percent sequence identity}

Sequence alignments with neurotropic Myxobolus species confirmed that the partial SSU rDNA sequence of the myxosporean from the brains of Atlantic salmon is identical to that of $M$. cerebralis. The $1 \%$ variation between the partial SSU rDNA sequence of the Atlantic salmon myxosporean and that of $M$. cerebralis is likely attributable to polymerase error and the inclusion of an undetermined base at position 877 (Fig. 4). The partial SSU rDNA sequence of the myxosporean also has high percent sequence identity with the neurotropic Myxobolus species $M$. arcticus and $M$. neurobius, as well as with one other member of the genus, $M$. insidiosus, whereas its percent sequence identity is much less with Henneguya doori or with Ceratomyxa shasta. The percent sequence identity of the Atlantic salmon myxosporean with $M$. squamalis follows the patterns demonstrated by the other $M$. species.

The partial SSU rDNA sequence of the myxosporean from Atlantic salmon comprises $61 \%$ of the total Myxobolus cerebralis SSU rRNA gene and includes both conserved and variable regions (Fig, 4). However, variable regions of the SSU rRNA gene exist outside of those sequenced and compared from the Atlantic salmon myxosporean and preclude a definitive characterization of the parasite based solely on this sequence data. Judging from those myxosporean species for which SSU rDNA sequences are available, the SSU rDNA sequence data from this investigation indicate that the myxosporean infecting the brains of Atlantic salmon is most likely $M$. cerebralis, which is consistent with previous morphologic assertions based on ultrastructural features of developmental stages (Frasca et al. 1998).

According to Halliday (1976), Myxobolus cerebralis has been identified in natural and farm-reared Salmo salar in Ireland, although no further details of its occurrence are given. At the marine rearing site where epizootic mortality was described (Rodger et al. 1995), 2 rivers flow into the south end of the lough, each of which has runs of wild Atlantic salmon $S$. salar and anadromous and partially anadromous brown trout S. trutta; in addition, a rainbow trout Oncorhynchus mykiss hatchery lies on one of these rivers (Frasca et al. 1998). Each of these salmonid populations could poten- tially serve as a source of $M$. cerebralis to the ecosystems of this geographic region; however, $M$. cerebralis has never been identified by histopathologic examination of farmed Atlantic salmon from these rearing sites during the course of the routine health surveillance regime instituted by the sea-farm in 1980. Fish from wild populations were not examined for evidence of infection by $M$. cerebralis as part of this study.

The assertion that this myxosporean from Atlantic salmon is Myxobolus cerebralis is supported by the fact that the multicellular developmental stages of this myxosporean have only been detected in the spinal cord and brain (Rodger et al. 1995), a distribution that is consistent with the migratory route of developmental stages of $M$. cerebralis in rainbow trout (El-Matbouli et al. 1995). However, neither spores nor infection of cartilage by developmental stages have been detected in infected smolts (Rodger et al. 1995, Frasca et al. 1998). Smolts with high-intensity parasite infection may die before cartilage infection and sporogony, as they have been reported to have the most severe pathology (Rodger et al. 1995). The fate of developmental stages in low-intensity infections of smolts has yet to be determined, although smolts can tolerate low-intensity infections without showing neurologic signs (Frasca et al. 1998). The absence of spores and cartilage involvement in infected smolts may also be attributable to normal growth and skeletal ossification of smolts, with replacement of target cartilage by bone thus preventing sporogony.

\section{Implications of molecular characterization}

The results of this study indicate that well-established molecular techniques can be successfully applied to formalin-fixed paraffin-embedded salmonid tissues and can generate useful sequence data from proliferative stages of myxosporeans, which may otherwise be difficult to taxonomically characterize based solely on their morphologic features. The sequence data from this myxosporean will be integral to the generation of probes for its detection in salmonid tissues and for the identification of possible alternate hosts.

Acknowledgements. The authors acknowledge the assistance of the technical manager and staff of the fish farm, Kerry Graves of the Department of Pathology, University of Texas Medical Branch, Galveston, for his assistance with in situ hybridizations, the DNA sequencing group of the HHMI Biopolymer/W.M. Keck Foundation Biotechnology Resource Laboratory at Yale University, Alex Bothell and John Collins of the Center for Instructional Media and Technology, University of Connecticut, for their assistance with graphics and photography, and Dr Karl B. Andree and Dr Dolores B. Antonio of the Fish Health Laboratory, University of California, Davis, for their help with the initial PCR and in situ hybridiza- 
tion experiments. This research was partially funded by the Storrs Agricultural Experiment Station, College of Agriculture and Natural Resources, University of Connecticut, and by a private aquaculture company in Ireland. This manuscript is recorded as Scientific Contribution no. 1810 by the Storrs Agricultural Experiment Station.

\section{LITERATURE CITED}

Andree KB, Gresoviac SJ, Hedrick RP (1997) Small subunit ribosomal RNA sequences unite alternate actinosporean and myxosporean stages of Myxobolus cerebralis the causative agent of whirling disease in salmonid fish. J Eukaryot Microbiol 44(3):208-215

Andree KB, Székely C, Molnár K, Gresoviac SJ, Hedrick RP (1999) Relationships among members of the genus Myxobolus (Myxozoa: Bivalvidae) based on small subunit ribosomal RNA sequences. J Parasitol 85(1):68-74

Antonio DB, Andree KB, McDowell TS, Hedrick RP (1998) Detection of Myxobolus cerebralis in rainbow trout and oligochaete tissues using a nonradioactive in situ hybridization protocol. J Aquat Anim Health 10(4):338-347

Bartholomew JL, Whipple MJ, Stevens DG, Fryer JL (1997) The life cycle of Ceratomyxa shasta, a myxosporean parasite of salmonids, requires a freshwater polychaete as an alternate host. J Parasitol 83(5):859-868

Crabbe ID, Hughes SS, Hicks DG, Puzas JE, Tsao GJY, Rosier RN (1992) Nonradioactive in situ hybridization using digoxigenin-labeled oligonucleotides. Applications to musculoskeletal tissues. Am J Pathol 141(3):579-589

El-Matbouli M, Hoffmann RW, Mandok C (1995) Light and electron microscopic observations on the route of the triactinomyxon-sporoplasm of Myxobolus cerebralis from epidermis into rainbow trout cartilage. J Fish Biol 46:919-935

Fedorko DP, Hijazi YM (1996) Application of molecular techniques to the diagnosis of microsporidial infection. Emerg Infect Dis 2(3):183-191

Frasca S Jr, Poynton SL, West AB, Van Kruiningen HJ (1998) Epizootiology, pathology, and ultrastructure of the myxosporean associated with parasitic encephalitis of farmed Atlantic salmon Salmo salar in Ireland. Dis Aquat Org 32 : $211-225$

Gan FY, Luk GD, Gesell MS (1994) Nonradioactive in situ hybridization techniques for routinely prepared pathology specimens and cultured cells. J Histotechnol 17(4): 313-319

Goodier JL, Davidson WS (1993) A repetitive element in the genome of Atlantic salmon, Salmo salar. Gene 131:237-242

Guiot Y, Rahier J (1995) The effects of varying key steps in the non-radioactive in situ hybridization protocol: a quantitative study. Histochem $\mathrm{J}$ 27:60-68

Gunderson $\mathrm{H} H$, Elwood $\mathrm{HJ}$, Ingold $\mathrm{A}$, Kindle $\mathrm{K}$, Sogin $\mathrm{ML}$ (1987) Phylogenetic relationships between chlorophytes, chrysophytes, and oomycetes. Proc Natl Acad Sci USA 84: 5823-5827

Halliday MM (1976) The biology of Myxosoma cerebralis: the causative organism of whirling disease of salmonids. J Fish Biol 9:339-357

Hedrick RP, McDowell T, Groff JM (1990) Sphaerospora ictaluri n. sp. (Myxosporea: Sphaerosphoridae) observed in the kidney of channel catfish, Ictalurus punctatus Rafinesque. J Protozool 37:107-112

Honma M, Ohara Y, Murayama $H$, Sako K, Iwasaki Y (1993) Effects of fixation and varying target length on the sensitivity of polymerase chain reaction for detection of human
T-cell leukemia virus type I proviral DNA in formalinfixed tissue sections. J Clin Microbiol 31:1799-1803

Impriam CC, Saiki RK, Erlich HA, Teplitz RL (1987) Analysis of DNA extracted from formalin-fixed paraffin-embedded tissues by enzymatic amplification and hybridization with sequence-specific oligonucleotides. Biochem Biophys Res Commun 142(3):710-716

Jackson DP, Hayden JD, Quirke P (1991) Extraction of nucleic acid from fresh and archival material. In: McPherson MJ, Quirke P, Taylor GR (eds) PCR: a practical approach. Oxford University Press, New York, p 29-50

Kent ML, Hedrick RP (1985) PKX, the causative organism of proliferative kidney disease (PKD) in Pacific salmonid fishes and its affinities with the myxozoa. J Protozool $32(2): 254-260$

Kent ML, Hervio DML, Docker MF, Devlin RH (1996) Taxonomy studies and diagnostic tests for myxosporean and microsporidian pathogens of salmonid fishes utilizing ribosomal DNA sequence. J Eukaryot Microbiol 43(5): 98S-99S

Lom J, Dyková I (1992) Protozoan parasites of fishes. Elsevier Science Publishers BV, Amsterdam, p 125-235

Merkelbach S, Gehlen J, Handt S, Fuzesi L (1997) Novel enzymatic immunoassay and optimized DNA extraction for the detection of polymerase-chain-reaction-amplified viral DNA from paraffin-embedded tissue. Am J Pathol 150:1537-1546

Mies C (1994) Molecular biological analysis of paraffinembedded tissues. Human Pathol 25(6):555-560

Mies C, Houldsworth J, Chaganti RSK (1991) Extraction of DNA from paraffin blocks for Southern blot analysis. Am J Surg Pathol 15(2):169-174

Molnár K (1993) The occurrence of Sphaerospora renicola $\mathrm{K}$-stages in the choroidal rete mirabile of the common carp. Folia Parasitol 40:175-180

Moran P, Reed KM, Perez J, Oakley TH, Phillips RB, GarciaVazquez E, Pendas AM (1997) Physical localization and characterization of the Bg/I element in the genomes of Atlantic salmon (Salmo salar L) and brown trout (S. trutta L.). Gene 194:9-18

Rodger HD, Turnbull T, Scullion FT, Sparrow D, Richards RH (1995) Nervous mortality syndrome in farmed Atlantic salmon. Vet Rec 137:616-617

Schlegel M, Lom J, Stechmann A, Bernhard D, Leipe D, Dyková I, Sogin ML (1996) Phylogenetic analysis of complete small subunit ribosomal RNA coding region of $M y x i-$ dium lieberkuehni: evidence that Myxozoa are Metazoa related to the Bilateria. Arch ProtistKd 147:1-9

Scullion FT, Scullion MG, Sparrow D, Rodger HD, Sheahan BJ (1996) Encephalitis and mass mortality of farmed salmon smolts in an isolated sea bay in Ireland. Vet Rec 138:161-162

Siddall ME, Martin DS, Bridge D, Desser SS, Cone DK (1995) The demise of a phylum of protists: phylogeny of myxozoa and other parasitic cnidaria. J Parasitol 81(6):961-967

Smothers JF, von Dohlen CD, Smith LH Jr, Spall RD (1994) Molecular evidence that the myxozoan protists are metazoans. Science 265:1719-1721

Sogin ML, Gunderson JH (1987) Structural diversity of eukaryotic small subunit ribosomal RNAs: evolutionary implications. Endocytobiology III. Ann N Y Acad Sci 503:125-139

Sogin ML, Elwood HJ, Gunderson JH (1986) Evolutionary diversity of eukaryotic small-subunit rRNA genes. Proc Natl Acad Sci USA 83:1383-1387

Wolf K, Markiw ME (1984) Biology contravenes taxonomy in the Myxozoa: new discoveries show alternation of invertebrate and vertebrate hosts. Science 225:1449-1452 